\title{
Correction to: What is known about the effects of exercise or training to reduce skeletal muscle impairments of patients with myotonic dystrophy type 1? A scoping review
}

Marie-Pier Roussel ${ }^{1,2,3}$, Marika Morin ${ }^{1}$, Cynthia Gagnon ${ }^{2,3,4}$ and Elise Duchesne $e^{1,2,3^{*}}$

Correction to: BMC Musculoskelet Disord (2019) 20:101 https://doi.org/10.1186/s12891-019-2458-7

\section{Abstract}

An incorrect attribution of the first study regarding the effect of exercise in DM1 mouse models needs to be revised.

\section{Main text}

In this article, we cited Manta et al. 2019 [1] as the first study to publish about the effects of exercise in DM1 mouse models This was an oversight considering that Ravel-Chapuis et al. 2018 [2] have reported in the last part of their "Results" section, presentation of the effects of wheel running on skeletal muscles of their DM1 mouse model. This article was published in October 2018 while the article of Manta et al. 2019 [1] was published in January 2019.

\footnotetext{
Author details

'Département des sciences de la santé, physiothérapie, Université du Québec à Chicoutimi, 555, boulevard de I'Université, Chicoutimi, Quebec G7H 2B1, Canada. ${ }^{2}$ Groupe de recherche interdisciplinaire sur les maladies neuromusculaires, Centre intégré universitaire de santé et de services sociaux du Saguenay-Lac-St-Jean, 2230 rue de I'Hôpital, Saguenay, Québec, Canada. ${ }^{3}$ Centre de recherche Charles-Le Moyne - Saguenay-Lac-Saint-Jean sur les innovations en santé, 2230 rue de l'Hôpital, Saguenay, Québec, Canada, Longueuil, Québec, Canada. ${ }^{4}$ Faculté de médecine et des sciences de la santé, Université de Sherbrooke, 3001, 12e Avenue Nord, Sherbrooke, Québec, Canada.

*Correspondence: elise1_duchesne@uqac.ca

'Département des sciences de la santé, physiothérapie, Université du Québec à Chicoutimi, 555, boulevard de I'Université, Chicoutimi, Quebec G7H 2B1, Canada

${ }^{2}$ Groupe de recherche interdisciplinaire sur les maladies neuromusculaires, Centre intégré universitaire de santé et de services sociaux du SaguenayLac-St-Jean, 2230 rue de l'Hôpital, Saguenay, Québec, Canada

Full list of author information is available at the end of the article
}

Published online: 24 May 2019

References

1. Manta A, Stouth DW, Xhuti D, Chi L, Rebalka IA, Kalmar JM, et al. Chronic exercise mitigates disease mechanisms and improves muscle function in myotonic dystrophy type 1 mice. J Physiol. 2019;597(5):1361-81.

2. Ravel-Chapuis A, Al-Rewashdy A, Belanger G, Jasmin BJ. Pharmacological and physiological activation of AMPK improves the spliceopathy in DM1 mouse muscles. Hum Mol Genet. 2018;27(19):3361-76.

(c) The Author(s). 2019 Open Access This article is distributed under the terms of the Creative Commons Attribution 4.0 International License (http://creativecommons.org/licenses/by/4.0/), which permits unrestricted use, distribution, and reproduction in any medium, provided you give appropriate credit to the original author(s) and the source, provide a link to the Creative Commons license, and indicate if changes were made. The Creative Commons Public Domain Dedication waiver (http://creativecommons.org/publicdomain/zero/1.0/) applies to the data made available in this article, unless otherwise stated. 